\title{
Brand Experience Concept for Elderly
}

\author{
Susisada INTRA ${ }^{1 *}$, Jantima KHEOKAO ${ }^{2}$, \\ ${ }^{1}$ A Doctor of Communication Arts in Marketing Communication (Candidate), Faculty of Communication Arts, \\ UTCC, THAILAND \\ ${ }^{2}$ Associate Professor, A director of the Doctor of Communication Arts Program in Marketing Communication, \\ Faculty of Communication Arts, UTCC, THAILAND
}

\begin{abstract}
.
While countries have taken 18 -115 years to transition from "aging" to "aged" society, Thailand is taking only 20 years, the fastest and earliest developing country to become an aged society. The signal is that the aging population is expected to grow a significant role in the marketing communications academic and the associated business sector. However, problems related to brand communication still occur with the elderly consumer, so the brand experience communication is important for building emotional bonds to creating a strong brand attachment between elderly consumers and brands. The purpose of this study is to the understanding of concepts related to the brand experience. To be used as a part to study Brand Experience Communication of the Elderly in Thailand. The study uses a qualitative research methodology. Through documentary research and synthesize 21 related research paper from 2103 to 2018 . Results have shown that Experience is going on when consumers search for a product, buy and use the service. The consumer experience can be divided into 1) Product experience, such as in the automotive industry, luxury goods. 2) Consumption experiences such as visits to museums and travel. 3) Experiencing touches with various stimuli related to brands, such as special events, product placement and 4) Shopping experience and service, such as library services, The hotel industry respectively. In summary, the brand experience can occur in many dimensions. It can happen throughout the Customer Journey.
\end{abstract}

Keyword: Aged society, Brand, Experience, Elderly Consumers, Marketing communication 


\section{Introduction}

\section{Thailand and the aged society}

Thailand is expected that this year (2019) will be the first time that the number of elderly people (60 years of age or older) will be greater than the population of children (under 15 years) and are entering the aged society in the year 2024 - 2025. The rapid change in population structure affecting the challenges in determining the direction to develop various countries. Whether it is the development of competition and economic growth, Urban development for the quality of life of the population, Health and medical development, Financial Planning and including the exchange of knowledge of the population of all ages for the development of skills and adapt to the changes that are the situation.

The United Nations (UN) states that during the years 2001 - 2100 will be the decade of the elderly which each country enters the aging society varies according to the environment of each place, such as economic growth medical development and food nutrition (Department of Older Persons, 2015; Chutarat Sangthong, 2017; Sukhothai Thammathirat Open University, n.d.) said that access to this increasingly aging society affects the quality of life of the population as a whole and is an important social phenomenon that all sectors need to prepare for urgent response.

In addition, Thailand is also the first country. In Southeast Asia that enters the elderly society, there is an opportunity to develop new products and services to support the aging society. Therefore, when neighboring countries step into the elderly society demand for products and services that have been developed to be able to generate revenue for the country (TDRI, 2019). Including changing the marketing paradigm aimed at consumers today marketing communicators at both academic and professional levels must keep up with changes and can develop knowledge for marketing communication or brand communication to be able to create and manage the brand effectively at the same time.

\section{The study of the elderly}

Over the past several years, the research strategy for the elderly and age society (2013 - 2016) in Thailand has received more serious attention. However, research is aimed at medical, public health, economy, wisdom society, the elderly products, designing a building that is conducive to the elderly and creating a model for caring for the elderly in various areas. Which has not identified the importance of research studies in various aspects of communication will be the bridge of connects in the development of knowledge, create understanding to make a relationship, create some attitudes or behavioral changes between the elderly and all sectors in society.

By surveying the elderly population in Thailand from the National Statistical Office (2014) found that the majority of the elderly in Thailand are in the early age (60 - 69 years) to 56 percent of all elderly, middle age (age 70 - 79 years), 30 percent and ages Late (age 80 years and over) 14 percent, respectively. And the survey of educational status of the elderly from the census and the elderly survey in Thailand also shows that the older generation has higher education and the elderly will live a long time and opportunity to live longer in society. Therefore, the reason that the elderly themselves need to be aware of the rapidly changing world 


\section{SOCIAL SCIENCES IN THE 21ST CENTURY}

and deserve to be educated skills development in various fields (Innovation and Creativity Administration Office, 2013) and the promotion of quality of life in all aspects continuously throughout life.

When studying the spending behavior of the elderly in the past by the Office of Small and Medium Enterprises Promotion (OSMEP) (2014), it was found that the expenses of the elderly are divided into two major groups: 1) health expenses and 2) recreation expenses. Because the elderly today have an attitude towards giving priority to living a better life both physically and mentally. Affecting the expansion of products and services for the elderly (OKMD, 2015). The elderly behavior in each age group has different characteristics. Development in various fields in order to meet the needs of elderly consumers in each group, it is a factor that every sector must pay much attention (Kasikorn Research Center, 2017).

The elderly consumer group has become a larger and more attractive marketing target. The study of the elderly consumers deeply to find various aspects related to the brand experience perspective to lead to the development of effective marketing communication in the context of different elderly appropriately and developed in parallel with social development as well as the development of various forms of products and services for the elderly in Thai society is therefore interesting.

\section{Marketing communication with the elderly}

At present, consumers have many choices and are more skilled in receiving information. From using modern technology not even the elderly who are ready to search and investigate products and services that what they need. With the opportunity to change their mind to support a brand that can meet more needs. Brand management with a standpoint and different from other competitors is an important strategy in business operations. Especially "Creating a brand experience" that attracts consumers when receiving positive experiences, resulting in an emotional bond and an attentive attitude including creating and maintaining a strong relationship between the consumer and the brand as well as creating brand loyalty in the future.

From the study of the origin of the brand experience, it was found that there was a connection with the brand communication. Creating a brand experience is one strategy that has been developed from the concept of integrated marketing communication as well. Which is often related to the subject of the communication and marketing communication channels in various forms including understanding consumer behavior in order to increase the ability to reach consumers in new contexts and the communication that occurs is all about communicating and presenting content about the brand that is meaningful to all consumers or recipients.

The study of the process of creating emotional relationships among consumers towards the brand both brand awareness and obtaining information from the brand, respect, friendship, trust, and brand loyalty to search and develop branded communication experiences. Especially in the elderly consumer group which has become an important target market (Kasikorn Research Center, 2018) and growing into the largest market in the future therefore being a source of attention to educators and trying to integrate marketing communication knowledge and various knowledge. That will create useful knowledge with consistency and efficiency to be applied. 


\section{Brand Experience Concept}

Now, the building brand experience comes to it's important to realize the one size doesn't fit all. Every organization and brand are unique, so the process of building brand experience cannot be expressed through a universal law (Darren Coleman, 2018) and consumers have more specific segmentation. The purpose of this study is to the understanding of concepts related to the brand experience. To be used as a part to study "Brand Experience Communication of the Elderly" in Thailand.

\section{Methods and Data Collection}

My analysis is based on a qualitative study with document analysis method. The study process is conducted by reviewing concepts, theories, and literature related to the brand experience. The search strategy in the EBSCOhost database, which is a study published through academic journals that have been certified before publication related to branding (Marketing) and appearing in the database between 2013 - 2018. Search terms used in the Business source complete and Communication and Mass Media complete databases, including "(brand and experience)", together with various documents or publications associated.

\section{Study Selection}

The researcher selects the relevant research from the Title, Abstract and then selects the original article (Full text) with the criteria for selecting the research that clearly indicates the importance. Following the Experiential Marketing concept for the development of branding in a variety of contexts. There is a total of 63 items and there are articles that have passed the selection criteria to be reviewed for 21 articles which will be analyzed with various documents or publications associated.

\section{Data Collection and Data Analysis}

The researcher analyzes the content to be consistent with the issues to be studied in order to understand the brand experience concepts and will be used as a guideline for creating further study instruments. The analysis of the data is based on the main points found in the data obtained from the study of the documents. From there, various issues were considered to be divided into sub-issues. And presenting data analysis results.

\section{Results and Discussion}

The study of brand experience comes from a combination of concepts from a variety of fields. Whether it is marketing psychology, philosophy, and management, which has received more and more attention in marketing education (branding) because the study shows that the brand experience is an important strategy for building long-term relationships with consumers (Khan \& Rahman, 2015). It also reflects the essence of brand management from a different perspective than in the past. Which means that the brand recognizes the interesting experience to consumers in every opportunity that consumers will interact with the brand. With reasons from Nowadays, consumers simply don't want products and services that are qualified or valuable to meet their needs but there is an expectation that the brand will be able to make a difference, stimulate and attract attention by creating a sense of sincerity within the mind (Schmitt, 2009). 
Khan \& Rahman (2015) argues that brand education and experience are largely based on the "Perception" of people who have the goal of understanding consumers or their target customers. That is specific and there is depth in the mind as well as being suitable for the study context to lead to the creation of brand management strategies create and communicate brand experience effectively. This shows that in accordance with the results of the study, it was found that the most published academic articles were selected using the highest qualitative method of study. Because it is a method of research that is appropriate for in-depth study of feelings experiences and situations that must be analyzed, interpreted according to the context or in particular cases before leading to studies that can create generalized conclusions. Although in the later stages of education efforts to find a concrete brand experience and can be measured even more since the study to find dimension and measure of the brand experience by Brakus and research team in 2009. Therefore, the results of the study found various issues and important to create understanding about the brand experience concept as follows.

\section{Brand Experience dimension}

From reviewing the concept of brand experience related to brands and consumers, it is found that in many academic studies, there are different or similar experiences. Whether it is the study of Brakus et al (2009), Gentile et al (2007), Schmitt (1999), Pine and Gilmore (1999) and is used as a concept in the study of academics to test, search and extend the knowledge related to many brands. When finding that consumers today are willing to pay or invest in order to acquire "Experience of happiness" rather than just making a purchase for a reasonable price and product attributes (Brakus et al., 2009; Schmitt, 2009). Especially the happiness from the experience that consumers receive with others often connect relationships, memories, and feelings to those who share experiences longer than the memories that have on things.

The basic concept related to this experience has been used to drive the "Experience Economy". By Joseph B.Pine and Jame H. Gilmore (1998) said that businesses need to create things that can transform into memories for consumers. That memory will become a product in another form called 'experience' and this experience must be a structure because it must be a real thing from the presentation through products and services, no matter when the opportunity to connect with consumers in a private and memorable manner. Something that organizations and brands must step into this change in order to create value for their brand sustainably. Therefore, the brand experience dimension will consist of 5 important dimensions including:

1. Sense Experience

The sensory experience involves creating the brand experience by stimulating consumer awareness through senses, including vision, exposure, hearing, taste, and smell. It can lead to an immersive and exciting experience (Schmitt, 1999). This dimension is accepted in the concept of Brakus et al (2009), Gentile et al (2007), Holbrook and Hirschman (1982) and Pine and Gilmore (1999). Examples of brand experience through senses such as decoration and atmosphere creation (sound, light, temperature, smell), product variety, both appearance, source and raw materials used in production facilities, cleanliness, etc. (Chen \& Haley, 2014; Cho et al., 2015; Dennis et al., 2013; Ditoiu et al., 2014; Donlan \& Crowther, 2014; Granot et al., 2013; Lazzi et al., 2016; Lee et al., 2015; Manthiou et al., 2016; Singh \& Ovsak, 2013; Shieh \& Lai, 2017; Tsui-Yii Shin, 2015).

\section{Feel Experience}


The feel experience is a combination of both emotional and emotional experiences of consumers. A dimension of brand experience that can be buttoned or stimulated by emotions and positively affects the brand's connection (Schmitt, 1999). This emotional response of consumers is an important component of the consumption experience (Gentile et al., 2007; Holbrook \& Hirschman, 1982; Pine and Gilmore, 1999). Whether it is an impression feeling happy about joining, using the service or using the product. Feelings that have received great attention from the staff or brand employees. A distinct form of product and service type, place decoration, employee uniform as well as being a reliable professional which affects consumer brand identity (Bhandari, 2016; Cho et al., 2015; Dennis et al., 2013; Donlan \& Crowther, 2014; Furey et ai., 2014; Lee et al., 2015; Manhas \& Dogra, 2013; Manthiou et al., 2016; Pillai \& George, 2015; Rahman et al., 2015; Rahman, 2014; Sahin et al., 2013; Singh \& Ovsak, 2013; Shieh \& Lai, 2017; Taillard et al., 2014; Tsui-Yii Shin, 2015).

\section{Intellectual Experience}

The idea or cognitive experience is to create a brand experience by attracting the attention of the consumer's intelligence into an experience that consists of creativity and imagination (Brakus et al., 2009; Holt, 1995; Schmitt, 1999); As well as stimulating curiosity for consumers. Which the brand experience in this dimension results in more consumer participation in creating a memorable experience and developing a relationship between the consumer and the brand (Hoch, 2002) such as responding to consumer needs, the ability to provide details and advice on products and services, safety standards, the brand has skilled and professional personnel. Including the products and services that are of value suitable for the price, etc. (Dennis et al., 2013; Furey et ai., 2014; Lazzi et al., 2016; Manthiou et al., 2016; Pillai \& George, 2015; Rahman et al., 2015; Sahin et al., 2013; Singh \& Ovsak, 2013; Shieh \& Lai, 2017; Tsui-Yii Shin, 2015).

\section{Act Experience}

The action experience focuses on the brand experience that occurs with consumers in a physical way. Therefore, creating activities in various ways Therefore is an important tool in attracting consumers. Due to the experience, entertainment and fun can create interest for consumers who want to escape from the truth (Pine \& Gilmore, 1999) and consistent with the study of Dubé and Lebel's (2003) about the happiness structure that emphasizes the physical experience that can make people feel happy. The experience of action, able to respond to the needs of consumers' activities there are forms of products and services that are consistent with the lifestyle of consumers. The experience of this brand resulting from this action has an effect on the repurchase (Chen \& Haley, 2014; Donlan \& Crowther, 2014; Lee et al., 2015; Manthiou et al., 2016; Sahin, 2013; Shieh \& Lai, 2017).

\section{Relate Experience}

Relate experiences can occur when consumers connect with others through social experiences. From the desire to develop themselves so that others perceive self positive (Schmitt, 1999). The value that consumers will receive in the sense of Holt (1995) is called the Social World, which can be described as being a pleasure to interact with others (Dubé and Lebel ', 2003; Gentile et al., 2007). In addition, the brand experience in the relevant experience dimension is also related to the brand, service type. Because it can help predict consumer 


\section{SOCIAL SCIENCES IN THE 21ST CENTURY}

satisfaction and loyalty (Nysveen et al., 2012), as well as brand experience from this relevant experience, will result in consumers telling the experience gained from the product and services recommend to others (Furey et ai., 2014; Granot et al., 2013; Lazzi et al., 2016; Manhas \& Dogra, 2013; Rahman, 2014; Rahman et al., 2015; Sahin., 2013; Shieh \& Lai, 2017).

When consumers experience the brand experience, it will cause "Spark by brand" that occurs within the consumer's mind and directly affects the brand interaction (Brakus et al., 2009). Although the brand experience is the same that does not mean that every consumer will feel or respond to the brand in the same way. In each consumer have different feelings because resulting in consumers having expressions of feelings, opinions, and behaviors different from the brands. Somethings related to that experience are subjective. Qualitative method for study in consumer for a niche market is very interesting.

\section{The Brand Experience Effective}

Brand experience communication that consistent brand communication objectives by communicating through different experience dimensions able to create communication effectiveness and affect different consumers as follows:

Table 1: The Brand Experience Effective

\begin{tabular}{|c|c|}
\hline Origin of brand experience & Advantage from the brand experience \\
\hline $\begin{array}{l}\text { Event Marketing } \\
\text { (Donlan \& Croether, 2014; Lee et al., 2015) }\end{array}$ & $\begin{array}{l}\text { Brand association through the introduction of new } \\
\text { brand experiences by allowing consumers to } \\
\text { participate through specific activities. An opportunity } \\
\text { for the brand to be able to communicate. The brand to } \\
\text { create awareness, increase sales for the brand and } \\
\text { create experiences for consumers to be impressed with } \\
\text { the brand for a long time. }\end{array}$ \\
\hline $\begin{array}{l}\text { Brand Contact } \\
\text { (Bhandari \& Saakshi, 2016; Chen \& Haley, } \\
\text { 2014; Cho et al., 2015; Manhas et al., 2013; } \\
\text { Manthiou et al., 2016; Pallai \& George,2015; } \\
\text { Rahman et al., 2015; Sigh \& Amber, 2013; } \\
\text { Taillard et al., 2014) }\end{array}$ & $\begin{array}{l}\text { Allowing consumers to experience brand identity in } \\
\text { every period of time when dealing with the brand, } \\
\text { especially the 'point of sale', that many studies believe } \\
\text { is a brand contact point. The most effective this brand } \\
\text { contact point affects behavior, purchase intention, } \\
\text { attitude, trust, the satisfaction that consumers have on } \\
\text { the brand. }\end{array}$ \\
\hline $\begin{array}{l}\text { Brand-relate Stimuli } \\
\text { (Cho et al., 2015; Furey et al., 2014; Lazzi et } \\
\text { al., 2016; Mahabubur, 2014; Rahman \& } \\
\text { TsuiYii Shin, 2015; Shieh \& Lai, 2017) }\end{array}$ & $\begin{array}{l}\text { Communication that can connect brand characteristics } \\
\text { when consumers contact the brand through a simple } \\
\text { brand touch point from brand names, purchase orders, } \\
\text { application forms, tax invoices or other things. That is } \\
\text { used to communicate with consumers that cause } \\
\text { branding during the purchase process or interaction } \\
\text { between all services and has a huge impact on } \\
\text { satisfaction to the loyalty of consumers towards the } \\
\text { brand. }\end{array}$ \\
\hline
\end{tabular}




\begin{tabular}{|l|l|}
\hline Storytelling & $\begin{array}{l}\text { The communication pattern of this brand experience is } \\
\text { more prominent and popular. Because the results from } \\
\text { stories that draw attention to consumers through } \\
\text { stories will bring knowledge and affect the minds of } \\
\text { consumers in a positive way. Storytelling makes } \\
\text { people obsessed and easily recognize the brand, as } \\
\text { well as the experience that occurs with consumers will } \\
\text { create a connection to the relationship that occurs with } \\
\text { the brand as well. }\end{array}$ \\
\hline $\begin{array}{l}\text { Word of Mouth } \\
\text { Taillard et al., 2014) }\end{array}$ & $\begin{array}{l}\text { The brand experience caused by WOM has a positive } \\
\text { impact on the emotional reactions of consumers. And } \\
\text { this recognition will be a key driver to authenticity } \\
\text { and trust. }\end{array}$ \\
\hline
\end{tabular}

Source: Literature Review by Author

In addition, in many studies (Bhandari \& Saakshi, 2016; Chen and Haley, 2014; Taillard et al., 2014) shows the benefits of creating an online brand experience that is believed to increase the effectiveness of awareness. And affect the trust in the brand that is an important factor in creating consumer engagement with the brand. Moreover, In the context of social media, participation in connecting the real world to consumers and influencing the real world of current marketing two-way control and interactive communication via social networks creates a more positive experience. Influence the quality of the relationship between the brand and the consumer as well as a tool that supports other marketing communication strategies to be more effective as well.

This study shows that consumption of products, services and purchasing experience all of this combined is a brand experience. Which can be said "Brand experience" is closely linked to consumer journeys and will have a huge impact on consumer behavior (Brakus et al., 2009; Hoolbrook, 2000; Pine \& Gilmore, 1998; Schmitt, 1999). The key issues in linking to the brand experience are consistent with Bernd H.Schmitt (2003) guidelines covering all three aspects:

1) The Product Experience

The product is the main focal for the customer experience. Because this product will first indicate the important features of the product. However, having a high level of usage is not enough to support brand decisions or attracting attention from consumers. Therefore, the experience that consumers will receive along with the product or service will result in impressive consumer experience with the brand.

2) The Look and Feel

Various looks and feelings around the product also known as the brand identity is another important aspect of the brand experience. Consumers do not want to recognize just the features of the product anymore. And looking at the product overview since the brand name, various symbols, packaging. And many other buying channels whether it is a store, point of sale, or even on the internet. The importance of the look and feel that creates this brand experience shows that the brand can offer various experiences. Can be anywhere that can reach consumers. 3) Experiential Communications

This experiential communication is based on a paradigm in the context that is relevant to the customer. That is creating the appropriate communication model that is primarily based on 


\section{SOCIAL SCIENCES IN THE 21ST CENTURY}

consumer needs and specific forms of communication are often combined with other marketing communication tools to increase the effectiveness of brand experience communication.

Figure 1: The Three key aspects of the Brand Experience

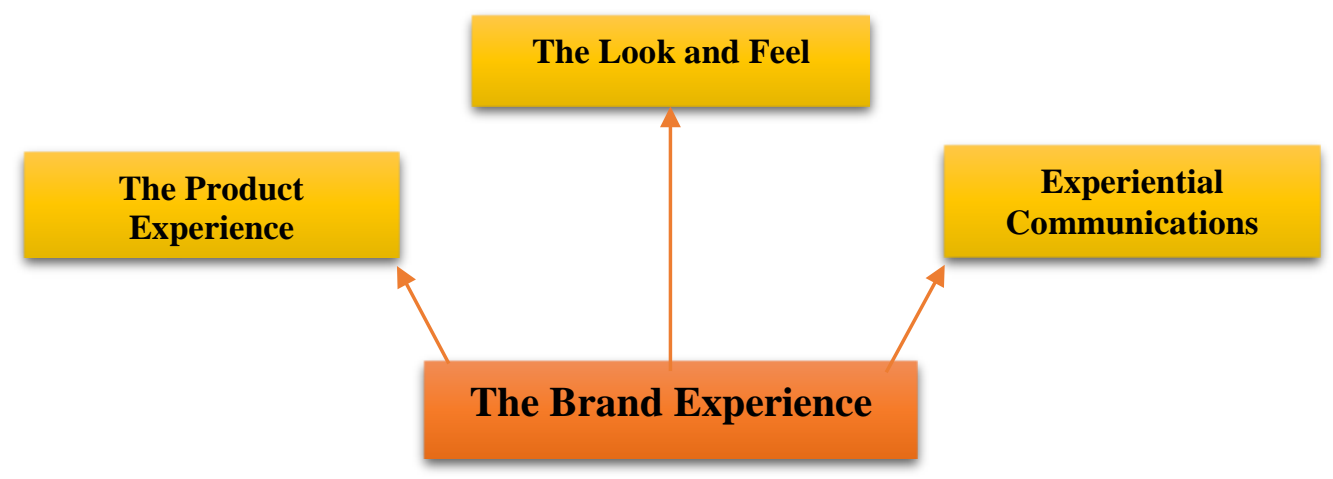

Source: Customer Experience Management. (Schmitt, 2003).

From these three key aspects, it shows that the brand experience is one of the strategies of brand communication that emphasizes access from direct interaction with consumers through emotion-related elements to create good memories. By specifying the source or method of creating important brand experiences through communication both offline and online. The effectiveness of the brand experience will create the impression and satisfaction that consumers have towards the brand to the brand loyalty as well as reflecting the identity and personality of consumers as well.

In the study of Sopark Panichpapiboon (2014), it was stated that the key factors that can strengthen the brand depend on the linking of what the brand communicates with consumers. And consumers feel that they are important or related to themselves. Therefore, the brand experience for good brand communication should be chosen to connect to what consumers desire (Desirability), as well as the brand that will be successful, must be able to differentiate connected which will result in consumers deciding that brand (Keller, 2008).

\section{Conclusion}

The results of this study show that the key issues that should be studied first are "consumers" because this subjective or individual study will lead to findings that are more specific to the group. Each consumer group has its own unique characteristics thus research to find the brand experience communication of the elderly will be consistent with the experiential marketing communication strategy based on the perception of the target consumer (Schmitt, 1999). In order to determine the approach and strategies for communicating brand experiences through various marketing communication tools as well as the design of events and environments. That inspires and increase feelings various sensory experiences with efficiency. 
The experience that passes the dimension, brand experience in various forms. Is a process that can create value between brands and consumers and that experience depends on the individual consumer. Hulten (2011) said that the sensory-related brand experience should be developed However, that experience is a complex phenomenon and needs to be explained from many perspectives through a holistic approach.

The aim of two important brand experience concepts: Consumer Satisfaction and Brand Loyalty from a literature review related to Khan and Rahman's brand experience (2015) Study the direction and development of brand experience concepts shows that it is consistent with that Drucker (1954) mentioned in The Practice of Management book, "There is only one purpose of a business: to create a customer.". Similar to the marketing objectives, the key is to create a valuable experience for consumers. And being a good business will affect consumers' feelings to the level of "Loyalty" and ready to continue to support the brand of the business even when paying higher prices.

This study will lead to a study of additional literature review to design the conceptual framework for research and design the research methodology that is appropriate for the context in which the study will continue. By defining the meaning of "Brand experience communication": the means of brand communication that is based on the experience of the sensory perceptions, feelings, cognition, actions that consumers can participate in on their own, and experience in the consumer social interaction.

Brand, is the leader of various experiences meaningful to consumers in any way allowing consumers to experience the identity of the brand at the same time, whether it is branding, packaging, environment, and communication through various throughout the journey of consumers both directly and indirectly. Starting from the process before making a purchase buying decision and after purchasing or using products and services. Brand Experience Communication has an important objective to allow consumers to interact with the brand and respond to the brand in a positive direction. 


\section{References}

\section{Book}

Bernd H. Schmitt. (2003). Customer Experience Management. Hoboken, N.J: Wiley. Darren Coleman. (2018). Building Brand Experience: a practical guide to retaining brand relevance. $1^{\text {st }}$ ed. New York, NY: Kogan Page Ltd.

Drucker, P.F. (1954). The Practice of Management. New York: Harper \& Row. Keller, K. L. (2003). Strategic brand management: Building, measuring, and managing brand equity. Upper Saddle River, N.J: Prentice Hall.

National Statistical Office. (2014). Report of the elderly population survey in Thailand 2014. National Statistical Office, Tax and Journal Public Company Limited. (In Thai) Sopark Panichpapiboon. (2014). Brand Management and Brand Equity Indicators in hospitality industry. Doctor of Philosophy Program in Communication Arts, Faculty of Communication Arts, Chulalongkorn University. (In Thai)

\section{Journal}

Bernd Schmitt. (1999). Experiential Marketing. Journal of Marketing Management, Vol.15, p53-67.

Bernd Schmitt. (2009). The concept of brand experience. Journal of Brand Management, Vol.16, p417 - 419.

BHANDARI, SAAKSHI. (2016). Library Experience Matters! Touchpoints to Community Engagement. CLEAR International Journal of Research in Commerce \& Management. Vol. 7 Issue 8, p76-84.

Chen, Huan; Haley, Eric. (2014). The wallpaper matters: Digital signage as customerexperience provider at the Harrods (London, UK) department store. Journal of Advertising. Vol. 43 Issue 3, p286-29.

Cherng G.Ding and Timmy H.Tseng. (2015). On the relationships among brand experience, hedonic emotion, and brand equity. European Journal of Marketing, Vol. 49, p994-1015.

Cho, Eunjoo; Fiore, Ann Marie; Russell, Daniel W. (2015). Leveraging sponsorship to achieve consumer relationship objectives through the creation of 'marketing spaces': An exploratory study. Psychology \& Marketing. Vol. 32 Issue 1, p28-48.

Chutarat Sangthong. (2017). Elderly society (Completely): High quality aging. Journal of Semi-academic Roosemala, Prince of Songkhla University. Vol. 38, Issue 1. p6-28. (In Thai) 
Dan Padgett and Douglas Allen. (1997). Communicating Experiences: A Narrative Approach to Creating Service Brand Image. Journal of Advertising, Vol. 26, No. 4, Services Advertising (Winter, 1997), p49-62.

Dennis, Charles; Joško Brakus, J.; Alamanos, Eleftherios. (2013). Customer-to-customer interactions and word of mouth: conceptual extensions and empirical investigations. Journal of Marketing Management. Vol. 29 Issue 3-4, p338-355.

DIŢOIU, Mihail-Cristian; STĂNCIOIU, Aurelia-Felicia; BRĂTUCU, Gabriel; ONIŞOR, Lucian-Florin; BOTOŞ, Andreea. (2014). Positioning university as a brand: distinctions between the brand promise of Russell Group, 1994 Group, University Alliance, and Million+ universities. Theoretical \& Applied Economics. Vol. 21 Issue 5, p37-50.

Donlan, Leah; Crowther, Philip. (2014). The sensory brand of the destination. Case study: Transylvania. Journal of Marketing Communications. Vol. 20 Issue 4, p291-306.

Doyle Yoon and Seounmi Youn. (2016). Brand Experience on Website: Its Mediating Role Between Perceived Interactivity and Relationship Quality. Journal of interactive advertising, Vol. 16, 1-15.

Dubé, L., \& Le Bel, J. L. (2003). The content and structure of laypeople's concept of pleasure. Cognition and Emotion, 17(2), p263-295.

Furey, Sheila; Springer, Paul; Parsons, Christine. (2014). Sports Stadiums as Meeting and Corporate/Social Event Venues: A Perspective from Meeting/Event Planners and Sport Facility Administrators. Journal of Marketing for Higher Education. Vol. 24 Issue 1, p99121.

Gentile Chiara, Spiller Nicola, Noci Giulano. (2007). How to sustain the Customer Experience: An Overview of experience Components that Co-create Value with the Customer. European Management Journal, 25 (5.), p395-410.

Granot, Elad; Russell, La Toya M.; Brashear-Alejandro, Thomas G. (2013). UNDERSTANDING THE MODELS OF CUSTOMER EXPERIENCE. Journal of Marketing Theory \& Practice. Vol. 21 Issue 1, p31-44.

Hoch, S.J. (2002). Product Experience Is Seductive. Journal of Consumer Research, 29, p48-454.

Holt, D. B. (1995). How consumers consume: A typology of consumption practices.

Journal of Consumer Research, 22(1), p1-16.

Hwai-Shuh Shieh; Wei-Hsun Lai. (2017). ATTRIBUTE DESIGN AND MARKETING STRATEGY OFBRANDING EXPERIENCE MUSEUMS. Journal of Economics \& Management. Vol. 28, p57-73. 17p.

Hultén, B. (2011). Sensory marketing: the multi-sensory brand-experience concept. European Business Review, 23, p256-273.

Iazzi, Antonio; Vrontis, Demetris; Trio, Oronzo; Melanthiou, Yioula. (2016). THE

MOTIVES AND BENEFITS OF USING CUSTOMER EXPERIENCE LED

DIFFERENTIATORS IN THE RE-LAUNCHING OF A FAILED PRODUCT: A CASE

STUDY OF CRANES \& COMPONENTS (P) LTD. Journal of Transnational

Management. Vol. 21 Issue 2, p84-9

Imran Khan and Zillur Rahman. (2015). A review and future directions of brand experience research. International Strategic Management Review, Vol.3, p1-14.

J. Joško Brakus, Bernd H. Schmitt, Lia Zarantonello. (2009). Brand Experience: What Is It? How Is It Measured? Does It Affect Loyalty?. Journal of Marketing: May 2009, Vol.

73, No. 3, p52-68. 
Joseph W. Alba; J. Wesley Hutchinson. (1997). Dimensions of Consumer Expertise. The Journal of Consumer Research, Vol. 13, No. 4. (Mar., 1987), p411-454.

Lee, Seungwon "Shawn"; Parrish, Charles; Kim, Ji-Ho. (2015). Value Creation and Consumption: When Consumer Creativity Generates Value in Online Forums. Journal of Quality Assurance in Hospitality \& Tourism. Vol. 16 Issue 2, p164-180.

Manhas, Parikshat Singh; Dogra, Jeet. (2013). Validation of a Fashion Brand Image Scale Capturing Cognitive, Sensory, and Affective Associations: Testing Its Role in an Extended Brand Equity Model. Journal of Services Research. Vol. 13 Issue 1, p75-93. Manthiou, Aikaterini; Kang, Juhee; Sumarjan, Norzuwana; Tang, Liang (Rebecca). (2016). Building behavioral intentions in automotive industry: Brand experience, satisfaction, trust, direct mail communication and attitudes toward advertising. International Journal of Tourism Research. Vol. 18 Issue 2, p105-115. 11p.

MORRIS B. HOLBROOK and ELIZABETH C. HIRSCHMAN. (1982). The Experiential Aspects of Consumption: Consumer Fantasies, Feelings, and Fun. Journal of Consumer Research, Vol. 9, p132-140.

Pillai, Anil; George, Babu P. (2015). Populence: Exploring Luxury for the Masses. Advances in Business-Related Scientific Research Journal. Vol. 6 Issue 1, p63-80. Rahman, Mahabubur. (2014). City Branding: Investigating a Brand Advocacy Model for Distinct Segments. Journal of Strategic Marketing. Vol. 22 Issue 7, p603-615. 13p. Rahman, Kaleel; Karpen, Ingo O.; Reid, Mike; Yuksel, Ulku. (2015). QUALITY MANAGEMENT PRACTICES AND TOURISM DESTINATION BRANDING: INTERRELATIONSHIP AND PREFERENTIAL STUDY OF THE COMPONENTS. Journal of Strategic Marketing. Vol. 23 Issue 4, p287-304. ŞAHIN, AZIZZE; TURHAN, GÜLDEN; ZEHİR, CEMAL. (2013). Consumer preference, satisfaction, and intentional behavior: Investigating consumer attitudes for branded or unbranded products. Business Management Dynamics. Vol. 3 Issue 4, p45-61. 17. Sahin, Safak; Baloglu, Seyhmus. (2014). Product Placement in Social Games: Consumer Experiences in China. Journal of Hospitality Marketing \& Management. Vol. 23 Issue 3, p239-265. 27p.

Singh, Rajesh; Ovsak, Amber. (2013). The Incorporation of Consumer Experience into the Branding Process: An Investigation of Name-Brand Hotels. Journal of Library Administration. Vol. 53 Issue 5-6, p344-358.

Taillard, Marie; Voyer, Benjamin; Glaveanu, Vlad; Gritzali, Alkmini. (2014). The relationships among brand experience, brand resonance and brand loyalty in experiential marketing: Evidence from smart phone in Taiwan. Advances in Consumer Research. Vol. 42, p381-386.

Tsui-Yii Shih. (2015). Differentiated brand experience in brand parity through branded branding strategy. International Journal of Electronic Business Management. Vol. 13, p85-96.

\section{Online}

B.Joseph Pine and James H. Gilmore. (1998). Welcome to the Experience Economy. Harvard Business Review. [Online]. Available: https://hbr.org/1998/07/welcome-totheexperience-economy Department of Older Persons. (2015). Statistics of the number of elderly people in 


\section{SOCIAL SCIENCES IN THE 21ST CENTURY}

Thailand in 2016. [online]. Available: www.dop.go.th (In Thai)

Innovation and Creativity Administration Office. (2013). Executive Summary:

Strategy for research on issues of elderly and elderly society (2015-2017). [online].

Available: https://www.kmutt.ac.th/rippc/nrct59/34s10.pdf_(In Thai) Kasikorn

Bank. (2018). Elderly Market: SME Treasure. [online]. Available:

https://www.kasikornbank.com/th/business/sme/KSMEKnowledge/article/KSMEAnalysis /Documents/Aging-Market_SME-Treasure_2018.pdf (In Thai)

Office of Knowledge Management and Development (Public Organization). (2015). NOW AGING: The opportunity. [online]. Available:

http://www.okmd.or.th/upload/pdf/2560/the\%20opportunity\%20by\%20okmd/Booklet_No w-Aging.pdf (In Thai)

Office of Small and Medium Enterprises Promotion (OSMEP). (2013). SME Connectivity. [online]. Available:

https://www.sme.go.th/upload/mod_download/Annual\%202013.pdf (In Thai) Sukhothai Thammathirat Open University. (2014). Aging society: implications for economic development. [online]. Available: http://www.stou.ac.th/stouonline/lom/data/sec/Lom0212/05_.02html (In Thai) Thailand Development Research Institute. (May 2019).

Longevity society: Thailand at a crossroad. [Online]. Available:

https://tdri.or.th/en/2019/05/longevity-society-thailand-ata-crossroad/ 